\title{
Green Economy and related concepts: an overview
}

\author{
Eleonore Loiseau', Laura Saikku², Riina Antikainen ${ }^{2 *}$, Nils Droste ${ }^{3}$, Bernd \\ Hansjürgens $^{3}$, Kati Pitkänen², Pekka Leskinen², Peter Kuikman ${ }^{4}$, Marianne Thomsen ${ }^{5}$ \\ ${ }^{1}$ Irstea, UMR Itap, Elsa Research group for Environmental Lifecycle and Sustainability Assessment, 361 rue J. \\ F. Breton, 34196 Montpellier cedex 5, France \\ ${ }^{2}$ SYKE, Finnish Environment Institute, P.O.Box 140, FI-00251 Helsinki, Finland \\ ${ }^{3}$ UFZ, Helmholtz Centre for Environmental Research - UFZ, Permoserstr. 15, 04318 Leipzig, Germany \\ ${ }^{4}$ Alterra, Wageningen UR, Droevendaalsesteeg 4, 6708PB Wageningen, The Netherlands \\ ${ }^{5}$ Aarhus University, Department of Environmental Science, Research group on EcoIndustrial System Analysis, \\ Frederiksborgvej 399, Postboks 358, DK-4000 Roskilde, Denmark \\ *Corresponding author: riina.antikainen@ymparisto.fi
}

\begin{abstract}
:
For the last ten years, the notion of a green economy has become increasingly attractive to policy makers. However, green economy covers a lot of diverse concepts and its links with sustainability are not always clear. In this article, we focus on definitions of green economy and related concepts and an evaluation of these concepts against the criterion of strong and weak sustainability. The article serves three purposes: Firstly, we identify and describe diverse theories, concepts, approaches and tools related to a "green economy". Among these are the theories of environmental economics and ecological economics, the concepts and approaches of cleaner production, waste hierarchy, bio-economy, industrial ecology, circular economy, nature-based solutions, and dematerialization through product-servicizing, and tools like life cycle assessment, and cost-benefit analysis. Secondly, we develop a framework that shows the capacity of the green economy concepts, approaches and tools to support the transition towards sustainability. Such a framework can serve as a heuristic to embed diverse concepts and approaches into a green economy framework. Thirdly, we briefly discuss green economy concepts with respect to their impact on strong and weak sustainability. Depending on the different concepts, approaches and tools identified in the green economy framework, different degrees of substitutability and trade-offs between environmental and economic benefits are allowed, and more or less structural changes of our modes of living are required. By discussing the notion of green economy and related concepts, approaches and tools we seek to make a contribution to their definitions and relationships as a prerequisite for operationalizing green economy.
\end{abstract}

Keywords: Green economy (GE), Environmental economics, Ecological economics, Sustainability, Substitutability, Trade-offs

\section{Highlights:}

- Green economy (GE) is an umbrella concept that lacks operationalization

- Different concepts related to GE are identified through bibliometric analysis

- These concepts are integrated in an heuristic framework for a GE

- Links between GE and sustainability are discussed 


\section{Introduction}

The United Nations (UN) conference on the environment and development held in Rio de Janeiro in 1992 formally adopted the concept of sustainable development defined by the Brundtland report as a "development that meets the needs of the present without compromising the ability of future generations to meet their own needs" (World Commission on Environment and Development, 1987). Twenty years later, the Rio+20 conference coined the concept "green economy" (Barbier, 2012). This popular concept is perceived as a pathway to sustainability by international organizations such as The World Bank (2012) and the United Nations Environment Programme (UNEP, 2011a). Moreover, green economy has been widely used to address the financial and climate change crisis (UNEP, 2011a), and is an essential element in achieving the climate mitigation targets refined in the Paris meeting. However, the connections between green economy and climate mitigation still need to be further explored. On a national scale, several countries are developing green economy strategies, policies and programs. In Asia, South Korea is among the forerunners. In 2009, the country announced a five-year plan to annually invest approximately 2 percent of its Gross Domestic Product (GDP) in the field of green growth ${ }^{1}$. China has also implemented a five-year plan (2011-2015) that devotes a large portion of its investments to green key sectors; e.g., renewable energy and technologies $^{2}$ (Mathews, 2012). In the European Union (EU), a range of measures related to the green economy concept are integrated into strategic documents such as the Europe 2020 and the Resource Efficiency Roadmap (Mazza \& ten Brink, 2012).

Compared with the application of green economy in policies, the concept itself has a longer history in the academic world. Green economy was first introduced by Pearce et al. in 1989 in response to the undervaluation of environmental and social costs in the current price system (Le Blanc, 2011). Since then, the concept has been broadened. Green economy has been defined by UNEP (2011a) as one that results in improved "well-being and social equity, while significantly reducing environmental risks and ecological scarcities". Green economy can be simply defined as being low-carbon, resource efficient and socially inclusive (UNEP, 2011a). UNEP emphasizes the preservation of natural capital, which includes ecosystems and natural resources. In addition to or sometimes interchangeably with green economy, the term green growth is often used (EEA, 2014). For a long time, "green growth" only applied to the growth of the eco-industry. However, the term is currently used for the growth of the entire economy (Jänicke, 2012). Green growth "is about fostering economic growth and development while ensuring that the natural assets continue to provide the resources and the environmental services on which our well-being relies. To achieve this it must catalyze investment and innovation which will underpin sustained growth and give rise to new economic opportunities" (OECD, 2011). Green growth is qualitative growth that is efficient in its use of natural resources, clean in that it minimizes pollution and environmental damages and resilient in that it explains natural hazards (World Bank, 2012). All these definitions show that green economy is an "umbrella" concept that encompasses different implications with regard to growth and well-being, or efficiency and risk reduction in the use of natural resources. These potentially contradictory implications require clarification regarding the capability of a green economy implementation to support a transition towards sustainability.

\footnotetext{
${ }^{1}$ The Republic of Korea's Five-Year Plan for Green Growth (For more information, see http://www.unep.org/PDF/PressReleases/201004_unep_national_strategy.pdf)

${ }^{2}$ China's 12th Five-Year Plan (2011-2015) (For more information, see http://www.kpmg.com/cn/en/issuesandinsights/articlespublications/publicationseries/5-years-plan/pages/default.aspx)
} 
Despite the popularity of the concept of green economy among international and national policy programs and institutions, its usefulness and appropriateness as a pathway to sustainability can be questioned (Le Blanc, 2011). Operationality of the green economy concept to achieve a transition towards sustainability, and a framework for its implementation and monitoring are still currently lacking.

The objective of this paper is to identify and describe the main theories and concepts related to a green economy and to illustrate their links to sustainability. Different concepts of a green economy are embedded in a heuristic framework that can be used to assess current green economy practices, cases and experiments. In particular, we elaborate on the underlying assumptions in terms of substitutability of productive inputs and implications regarding notions of weak and strong sustainability. The framework was tested in various European cases and experiments with a wide cross-sectoral approach of different geographical and temporal scales in two follow-up studies: considering the critical factors of success by Pitkänen et al. (2016) and assessing institutional conditions that facilitate their transition towards a green economy by Droste et al. (2016).

The paper is composed of six main sections. Following the introduction, in section 2 a bibliometric analysis is conducted to identify and categorize the main theories, concepts, practical approaches and tools used in the literature as green economy strategies. In section 3, these different elements are described and briefly characterized with respect to sustainability. Based on the relations between these theories, concepts, approaches, and tools in the context of a green economy, in section 4 we provide a conceptual mapping heuristic to highlight the scope of a green economy. In section 5, this generic framework is used to discuss the implications of different theoretical and applied stances for the capabilities of the green economy concept to support transition towards sustainability. We conclude with some summarizing remarks (section 6).

\section{Identifying dimensions and characteristics of a green economy: a bibliometric analysis}

\subsection{Keywords related to green economy}

We conducted a bibliometric analysis in order to identify the main keywords related to the term "green economy" in the scientific literature since 1990. To this end, we used the bibliographic database Scopus as it is likely currently the best tool available for electronic literature search, particularly for articles published after 1995 due to - compared to other databases - its wider subject and journal range (Falagas et al., 2008). In addition, it allows the research of keywords. The literature research found 877 documents where the term "green economy" is mentioned in the title, the abstract or the keywords, occurring jointly with altogether 157 different keywords, respectively. These different keywords can be classified into several semantic fields (Figure 1). 


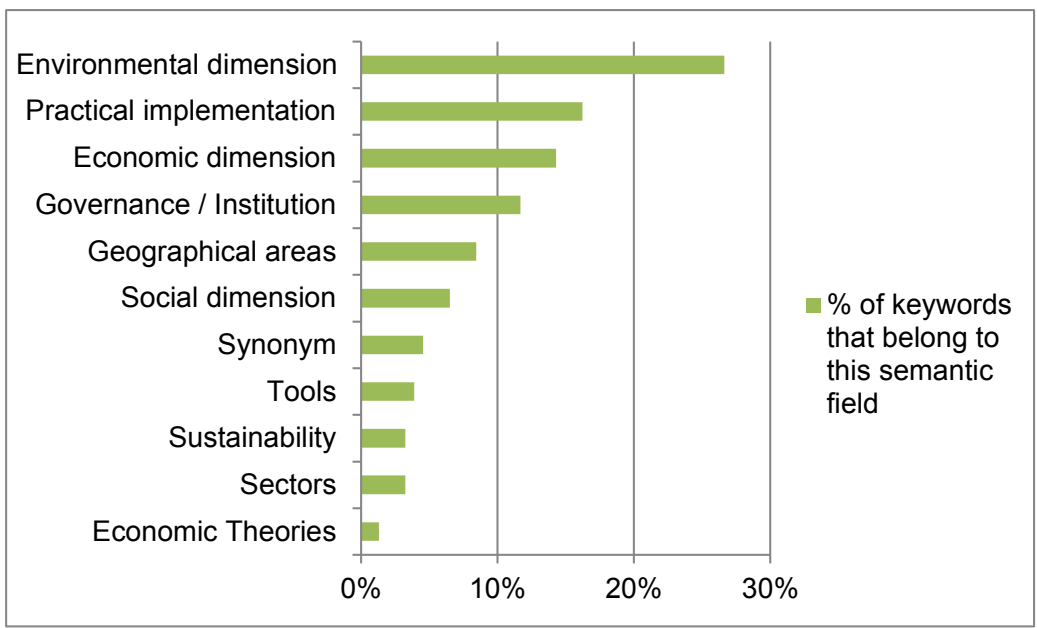

Figure 1 Semantic fields of the keywords related to "green economy" found in the literature research on the bibliographic database Scopus

The results show that over half of the keywords related to "green economy" belong to the semantic fields of environmental and economic dimensions. The environmental dimension covers different environmental issues (e.g., climate change, renewable resources, energy, natural capital), whereas the economic dimension encompasses different economic aspects such as development, growth, cost, or competitiveness. The social dimension is less represented. The emphasis on these three aspects of sustainability proves the strong links between green economy and sustainability. In addition, several keywords are used for the implementation of green economy in practice showing the interest of the research community in providing operational concepts. The semantic field of governance is also important and emphasizes the needs to define and analyze governance approaches that can support the concept of green economy. Moreover, a lot of keywords refer to "geographical areas" in order to highlight that various national and regional policies towards green economy have already been implemented. Finally, a semantic field on "tools" has also been identified. It points at connections with tools that can be used to assess and monitor the implementation of green economy in practice.

\subsection{Keyword occurrence in the scientific literature}

Figure 2 provides more details on the main keywords related to the different semantic fields. These keywords correspond to those that have the highest occurrence ratios. These ratios are quantified by dividing the number of times the studied term is associated with "green economy" by the number of times the term "green economy" appears alone. The results show that in more than $35 \%$ of cases, the term "green economy" is associated with the particular keywords of "sustainable development" or "sustainability". This relationship point outs that green economy can often be perceived as a pathway to sustainability. Second, figure 2 brings information on the important terms related to the three dimensions of sustainability (environmental, economic and social). One interpretation of the results is that "green economy" can often be seen as a way to decrease pressure on resources, climate change and emissions, while at the same time ensuring economic growth and employments. In addition, there are more connections between "green economy" and the "environmental economics" theory than between "green economy" and the "ecological economics" theory.

Practical implementation of green economy is also important in the keywords. A green economy can be supported by environmental or energy policies and requires innovations and investments as suggested by figure 2. Six main concepts and approaches are identified in figure 2, i.e., energy efficiency, green technology, pollution control, bioenergy, recycling and 
circular economy. In order to assess the environmental impacts of implementing green economy in practice, Life Cycle Assessment (LCA) is the most used tool, followed by carbon footprint and Cost-Benefit Analysis (CBA), according to the occurrence ratio values.

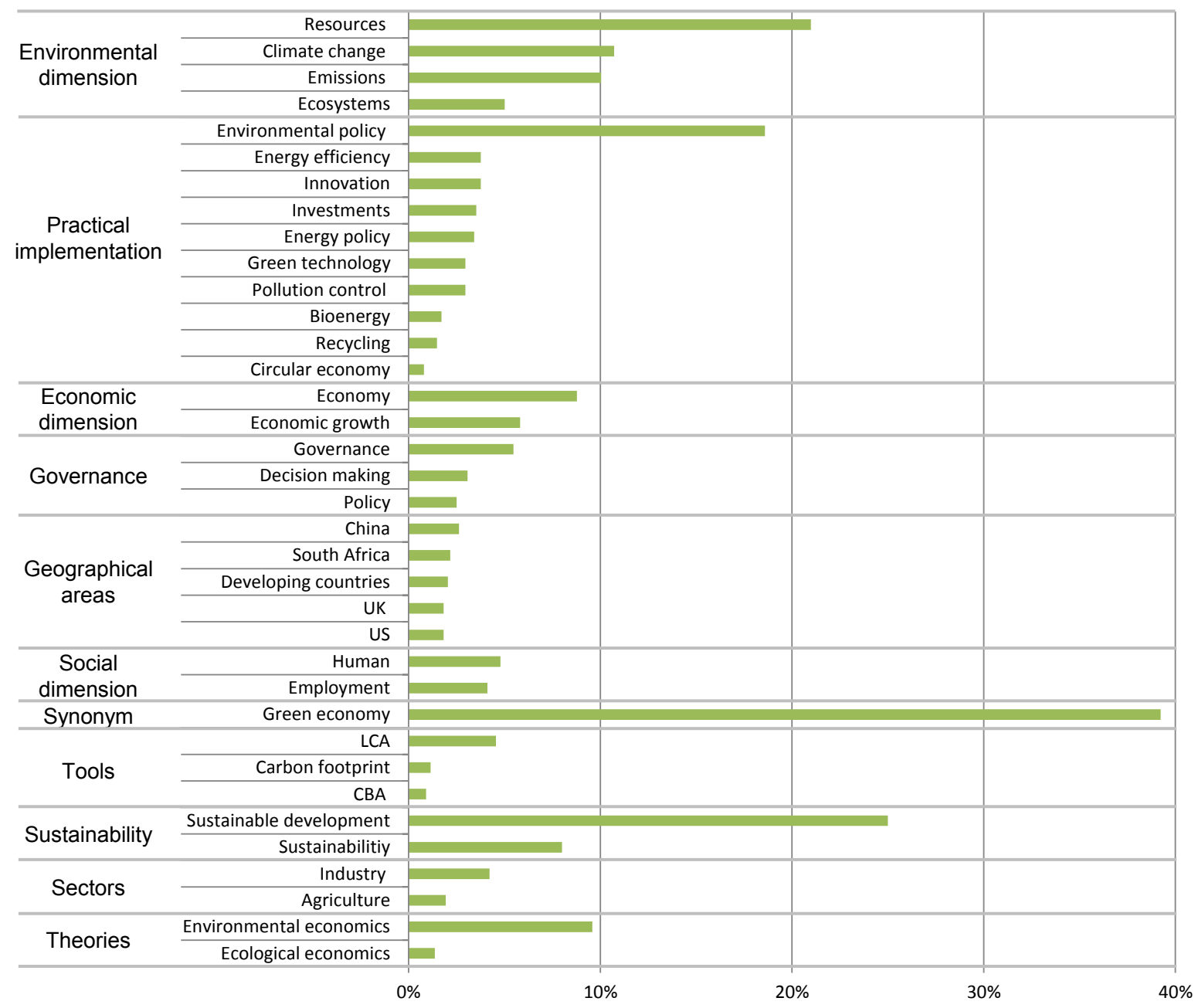

Figure 2 Occurence ratios of keywords classified according to their semantic fields

In addition to the scientific literature, international institutions also refer to the different practical concepts and approaches of green economy. For instance, UNEP (2011a) provided an exhaustive list of concepts and approaches that includes resource efficiency, cleaner production, the waste hierarchy (reduce, reuse, recycle, and repair), circular economy, LCA and CBA. These institutions also introduce emerging concepts such as green infrastructure (UNEP, 2011a), bioeconomy (EC, 2012) or product-service system (PSS) (UNEP, 2015). Even if these concepts do not appear in the keyword research above, it seems important to consider them when studying green economy.

All these theories, concepts, approaches and tools are briefly described in the following section. The goal is to illustrate their links with green economy and provide background information to discuss the relationships between "green economy" and sustainability. 


\section{Theories, concepts, approaches and tools for a green economy}

\subsection{Underlying theories: environmental economics and ecological economics}

\subsubsection{Environmental economics}

According to neoclassical economists, environmental issues are due to the inefficient use of natural resources and the undervaluation of natural capital (Borel-Saladin and Turok, 2013). The underlying assumption is that man-made and natural capitals are substitutable (Bina and La Camera, 2011). One of the main assumptions of this perspective is that economic growth and sustainable use of resources can be achieved simultaneously. This so-called Porter hypothesis deserves special attention because it assumes that there can be win-win solutions for both the economy and the environment (Porter and Van der Linde, 1995). It proposes that environmental regulation may spur entrepreneurial innovation, improve business performance, and thus benefits not just the environmental but also the economic dimension (Ambec et al., 2013). This perspective is optimistic regarding the aptitude of humankind to solve any problems that may arise with resource depletion (Williams and Millington, 2004).

The starting point of environmental economics is the concept of external effects (Pigou, 1920). Thus, the strategy pursued by environmental economics is to set prices right ("internalization") by providing an accurate valuation of this capital. To evaluate natural capital, the external effects are estimated using different methods and suggestions are made to internalize these effects (Rennings and Wiggering, 1997). External environmental costs can have a variety of forms ranging from local (e.g., noise of an airport) to global (e.g., greenhouse gas emissions and long-range transboundary air pollution). External benefits can be related to the use of "commons" such as regional spill over benefits from watershed protection areas. If private behavioral incentives do not reflect costs or benefits to third parties or society as a whole, the decisions taken will not lead to a social optimum and may lead to decreased social welfare. The costs and/or benefits that a particular activity incurs to a third party should be addressed by economic instruments in such a way that the respective actor incorporates these values into decision making. A broad set of potential instruments can be used for internalization, i.e., command and control, taxes, subsidies, tradable permits, liability law, or payments for ecosystem services.

The underlying assumption of these approaches is that, as soon as society as a whole gets the prices right (reflecting external costs), the non-sustainable use of natural resources will come to a halt (see Williamson 1994, on the development of institutional economics). This assumption implies the notion of weak sustainability where constant welfare over time can (i) be obtained by substituting natural capital by man-made and human capital and (ii) natural capital is not characterized by critical thresholds so that environmental degradation is reversible (Pelenc and Ballet, 2015). These assumptions are often formalized in terms of a welfare functions with different capital goods as inputs and particularly mathematical expressions about the degree of substitutability, for example in terms of input elasticities.

\subsubsection{Ecological economics}

In ecological economics, the economy is defined as a subsystem of the natural which sets limits on the physical growth of the economy. Economic systems are ultimately constrained by the Earth's biophysical limits, and society must adapt their economic system accordingly to operate within a safe operating space (Bina and La Camera, 2011; Kennet and Heinemann, 2006). 
Ecological economics concepts emerged at the end of the 1980s inspired by previous multidisciplinary research based on natural and social sciences. This ecological economics school attempts to model socio-ecological systems by analyzing cause-effect-relationships and dynamic processes with the environment. These integrated and biophysical perspectives of environment-economy interactions aim at contributing to solutions for environmental problems (Ekins et al., 2003; van den Bergh, 2001). Among these solutions, great emphasis is placed on structural changes within economy and society such as creating a more small-scale decentralized way of life based upon greater self-reliance in order to create social and economic systems that are less destructive towards nature (Williams and Millington, 2004). For this purpose, physical or ecological indicators (e.g., material input per service unit, the ecological footprint, and the critical natural capital) based on the concept of dematerialization and the conservation of non-substitutable natural capital are developed (Ekins et al., 2003; Farley, 2008; van den Bergh, 2001). Accordingly, the concept is rather based on physical measurement and ecological knowledge to assess critical thresholds but it also includes the study of institutions, property regimes and environmental governance mechanisms (Vatn, 2007).

The dematerialization of economies refers to reducing material or energy use per unit of service output. Dematerialization refers to lowering the volume and toxicity of flows in human linear systems and implies closing cycles of materials or energy (de Bruyn, 2002). Dematerialization reduces emissions, as according to the law of conservation of mass every material input sooner or later turns up as emissions or waste to be an output from the system. However, striving for dematerialization does not always lead to a relative decrease in the use of resources due to rebound effects; i.e., efficiency gains may lower the prices which may increase consumption (Herring 2006), or they may lead to a regional shift of polluting activities. Consequently, technological improvements are necessary but not sufficient to achieve dematerialization, and structural changes and sufficiency policy initiatives must additionally be conducted to ensure sustainable management of resources (Lorek and Spangenberg, 2014). Such a perspective is built upon the assumption that there are ultimate limits to the substitutability of natural capital and man-made capital and that at least certain (critical) stocks of natural capital must be maintained in order to obtain sustainability, which is a strong sustainability notion.

In the following we analyze different concepts and their relationships with the notion of green economy. We make the distinction between "well-established" concepts and tools which have been discussed for a longer period, and "emerging" concepts that came up recently.

\subsection{Well-established concepts, approaches and tools}

\subsubsection{Cleaner production and resource efficiency}

The term cleaner production was defined by UNEP in 1990 as "the continuous application of an integrated environmental strategy to processes, products and services to increase efficiency and reduce risks to humans and the environment". This approach was a paradigm shift because it stated that it was more appropriate to attempt to prevent pollution rather than treat pollution with end-of-pipe techniques (El Kholy, 2002). UNEP recently broadened the definition of cleaner production to include resource efficiency, which is a key element of the transition towards a green economy (UNEP, 2016). Consequently, an emphasis was placed on developing cleaner technologies that generate less pollution and waste and that make more efficient use of materials and resources. Initially, efforts were exerted to develop "green products" that generally focused on one single environmental issue. More systematic approaches to designing for the environment emerged in the 1990s; this was known as eco- 
design (Roy, 2000), or as design related to environment or green design. It refers to an approach of product designed for zero waste production, take-back and reuse, in which the life-cyclic environmental impacts of a product are considered (section 4). The role of design phase in reducing environmental impacts in the production process, in packaging and logistics, during the use phase and in disposal is crucial, because it is the main phase affecting factors such as the product's material and substance content, durability and possibilities to disassembly. In addition to decreased environmental impacts, the promotion of cleaner production among firms can lead to net job creation. However, these results hold only for highly skilled labor and specific policy programs that differentiate between the types of ecoinnovations that should be designed (Pfeiffer and Rennings, 2001).

Resource efficiency and eco-design aim mainly at improving the use of natural resources in the value-chain of production focusing on firms and their behavior by focusing on reducing environmental emissions and waste by technological innovations. This is consistent with the environmental economic's assumption that the transition towards sustainability can be supported by constant improvements in the rate of substitution of natural capital into manmade or human capital.

\subsubsection{Waste hierarchy: reuse, repairing, recovery and recycling}

The waste hierarchy approach along with the waste prevention (EC, 2008) are important elements of green economy by improving resource efficiency, reducing need for raw materials and aiming at closing the material flows. The stages of waste hierarchy are first prevention, then reuse, recycle, recovery, and finally disposal. Moving towards the bottom of the hierarchy, the quantity of auxiliary energy and resources needed for waste management and the losses of materials and energy increase. By waste prevention, these negative impacts can be avoided. Waste prevention starts in the designing and processing of products. The reuse of goods is means to use of a product again for the same purpose in its original form or with minimal upgrading. Material recycling describes the process of recovering materials of a product for the original purpose or for other purposes. A process of converting materials into new materials of higher quality and increased functionality is up-cycling, whereas a process of converting materials into new materials of lesser quality and reduced functionality is called down-cycling. The recovery of materials includes the processing and conversion of the original materials into new products. Energy recovery turns materials into heat, electricity or fuel. Safe disposal, preferably via return to the extraction and production site, is the final option to manage waste as a resource in a green economy. Despite of the environmental benefits of implementing the waste hierarchy, waste generates economic activities, and sophisticated incentives are required to decouple economic growth from waste generation (Bartl, 2014).

The waste hierarchy approach is mainly focused on reducing throughput and thereby the environmental pollution of production processes. As such it aims at increasing the resource efficiency similar to the cleaner production approach; it differs from the latter for the stronger emphasis on waste reduction and control of harmful substances. In this respect waste hierarchy comes closer to safeguarding the planetary boundaries according to a strong sustainability perspective.

\subsubsection{Industrial ecology and circular economy}

Industrial ecology is a research field ${ }^{3}$ interested in integrating notions of sustainability into the environmental and economic systems. The use of energy and materials is optimized, and the

\footnotetext{
${ }^{3}$ Industrial ecology has been defined as a field, discipline, area of study, and a discourse (Allenby 2006).
} 
generation of waste is minimized to move from linear throughput to closed-loop materials and energy use (Ehrenfeld and Gertler, 1997). The core elements of industrial ecology are the use of biological analogy, the use of a systems perspective, the role of technological change and dematerialization from a forward-looking perspective (Lifset and Graedel, 2002).

When implementing industrial ecology in practice, industrial symbiosis (IS) aims at engaging traditionally separate activities in physical exchanges of materials and energy flows. These physical exchanges can occur within a facility, firm, or organization; among firms collocated in a defined eco-industrial park; and among firms organized "virtually" across a broader region (Chertow, 2000). Although industrial symbiosis implementations are usually concentrated on the level of industrial parks, larger regional areas may be more suitable for closing material loops and creating sustainable industrial ecosystems (Sterr and Ott, 2004). Furthermore, IS has been recently defined as a path to green growth because it engages organizations in a network to foster eco-innovation and encourages them to make new investments and change business practices, and it also stimulates research and development, new businesses, and joint ventures (Lombardi and Laybourn, 2012).

Following in the footsteps of industrial ecology (Mathews and Tan, 2011), the concept of circular economy is becoming increasingly popular in civil society with the works conducted by The Ellen MacArthur Foundation (2012). The Foundation defined circular economy as "an industrial economy that is restorative by design, and which mirrors nature in actively enhancing and optimizing the systems through which it operates". "Circular economy builds on the concepts of waste prevention and resource efficiency by showing where the greatest benefits are to be realized, and by emphasizing the need to consider the sustainability of the sources of raw materials, as well as their fate. It adds to the development of EU waste and resources policy" (Hill, 2015). As such, synergies exist between the two concepts in supporting an upward transition in the waste hierarchy, e.g., by transforming the by-products of one industry into valuable resources for one or several other industries.

Both the industrial ecology and circular economy approaches move beyond the firm level foundations of the resource efficiency and waste hierarchy approaches. By broadening the focus to inter-firm co-operations and designing economy-wide circular resource flows at regional and global level, these approaches take a macro-economic perspective (Lifset \& Graedel 2002). By focusing not just on reducing the resource-efficiency and material throughput but by closing the loop of material flows from a linear to a circular flow they take a stance more congruent with the strong sustainability perspective of ecological economics.

\subsubsection{Life cycle and material flow based tools and methods}

There are several life cycle and material flow-based tools of industrial ecology and economics to assess the sustainability of a green economy. Material Flow Analysis (MFA) refers generally to the analysis of the throughput of process chains comprising extraction or harvest, chemical transformation, manufacturing, consumption, recycling and disposal of materials (Bringezu and Moriguchi, 2002). MFA is based on accounts in physical units and quantifies the inputs and outputs of those processes, MFA can be practiced on the levels of substances (substance flow analysis, SFA), materials (MFA) or products within firms, sectors or regions. The product level MFA normally denotes the life cycle inventory phase of LCA. This level is a widely used tool for assessing the environmental impacts of a product or service from "cradle to grave" (Finnveden et al., 2009). In environmental LCA, impacts such as climate change, acidification and toxic emissions are considered. Environmentally Extended InputOutput (EEIO) model is an elaborated version of the classical input-output (IO) model describing the interdependencies between different sectors of the economy (Leontief (1936). 
In EEIO, also environmental impacts are included (e.g., Kitzes, 2013; Koskela et al., 2011). EEIO can be viewed as a LCA tool; however, instead of production process-based analyses, it operates at the sector-level of the economy.

Tools to assess economic dimension of the green economy include Life Cycle Costing (LCC), which measures the total cost of an asset over its life cycle including capital costs, maintenance costs, operating costs and the asset's residual value at the end of its life (Sesana and Salvalai, 2013). Social Life Cycle Assessment (S-LCA) is developed to evaluate the social dimension using indicators such as employment, workplace health and equity (Benoit Norris, 2012; Macombe et al., 2013). Compared to environmental LCA, S-LCA has been applied to a limited number of real-life case studies; however, the topic is under active development (e.g., Benoit Norris, 2012; Macombe et al., 2013). It is also possible to integrate environmental, economic and social aspects with the concept of Life Cycle Sustainability assessment (LCSA) (Guinée et al., 2011; Heijungs, 2010; Hoogmartens et al., 2014) to have an overall picture of the impacts.

\subsubsection{Cost benefit analysis}

Cost-benefit analysis (CBA) is a decision support tool used to assess the welfare effects of a project or an investment and has its roots in the welfare measures of producer and consumer surplus (Hanley and Barbier, 2009; Hanley and Spash, 1993; Hansjürgens, 2004; Sen, 2000). A comprehensive CBA can be used to compare the environmental, economic and social dimensions of different green economy strategies (UNEP, 2011a). As such, CBA requires that all project-related disadvantages (costs) and advantages (benefits) are identified and monetized at their margin (the price of an additional unit). Future streams of costs and benefits are integrated with their net present value (the discounted total value of future streams).

A prerequisite for a complete welfare assessment is that all project related costs and benefits are assessed. Thus, the concept of Total Economic Value (TEV) is often used to include both use values and non-use values (Pearce and Moran, 1994; TEEB, 2010). Costs and benefits of goods and services that are not traded in markets (such as many ecosystem services) do not have a market price. Stated preference methods can be used to assess a willingness to pay as a proxy for the marginal change in the utility obtained, or preferences for willingness to pay can be obtained from individuals' behavior on markets (revealed preferences).

\subsection{Emerging concepts and approaches}

\subsubsection{Green infrastructure and nature-based solutions}

One of the newly emerging concepts in environmental policy is the concept of nature-based solutions. Implementing nature-based solutions requires designing multifunctional landscapes that contribute to sustainable resource management systems that foster the development of a green economy. Nature-based solutions can simultaneously provide multiple benefits such as flood control, carbon storage, raw materials, human health and biodiversity if its ecosystems are healthy (Mazza et al., 2011). Green Infrastructure (GI) is one example of a nature-based solution. In the EU, GI is a strategically planned network of natural and semi-natural areas, which are viewed as a cost-effective alternative or complement to grey, man-made infrastructure to satisfy human needs (European Commission, 2013a). The concept of GI has been developed to upgrade urban and peri-urban green spaces in terms of both quality and quantity and to emphasize the importance of their multifunctionality as well as their role in the interconnection between habitats (Tzoulas et al., 2007). The European Commission's 
strategy on GI plans to invest in nature-based solutions to conserve and enhance natural capital such as protected watersheds for clean drinking water, natural floodplains to provide protection, or urban greenspaces to improve climate resilience. GI are designed and managed to provide a wide range of environmental services. GI often yield high economic returns on investment through e.g., tourism and recreation, climate or air quality regulation and provisioning services such as biomass production (European Commission, 2013b; Nellemann et al., 2010). A particular strategy to increase biodiversity in abandoned farmlands is rewilding (Navarro and Pereira, 2012).

As such the concept of nature-based solutions is focused on investments into natural capital that enhance the supply of multi-benefit ecosystems. It aims not just at environmental protection through the reduction of pollution but also incrementing the stock of natural capital. Therefore, nature-based solution is the only approach that complies with strong sustainability. But it also entails a micro perspective since it aims at public and private investors to facilitate nature-based solutions in urban and rural landscapes.

\subsubsection{Bioeconomy}

Bioeconomy has been defined by the OECD (2009) to include all economic activities that are linked to the development and the use of biological products and processes. However, the definition is not univocal. Georgescu-Roegen's (1975, p. 369) bioeconomic theory refers to the mankind's survival depending on "the three low-entropy sources - free energy received from the sun, and the free energy and the ordered material structures stored in the bowels of the earth", and represents a radical criticism of neo-classical theory (Bonaiuti 2011). Following OECD approach, bioeconomy, bio-based economy or knowledge based bioeconomy can be viewed as synonymous (McCormick and Kautto, 2013). Bioeconomy relies on the development of biotechnologies that "apply science and technology to living organisms, as well as parts, products and models thereof, to alter living and non-living materials for the production of knowledge, goods and services" (OECD, 2009). Biotechnology provides wide perspectives for progress in primary production (e.g., plant and animal breeding), health (e.g., pharmacogenetics) and industries (e.g., bioremediation, biosensors) while decreasing the dependence on non-renewable resources and ensuring food, environmental, social and economic security through job creation and competitive position. The European Commission (2012) defined bioeconomy as "an economy using biological resources from the land and sea as well as waste, including food wastes, as inputs to industry and energy production. It also covers the use of bio-based processes to green industries". This definition remains under debate because it can be argued that the EU policy framework is dominated by an agro-industry perspective and that more emphasis should be placed on a public-good oriented concept of the bioeconomy with the inclusion of agro-ecology concepts and local knowledge (Schmid et al., 2012). Nonetheless, the concept is popular among European institutions with the establishment of a bioeconomy observatory ${ }^{4}$, and funding mechanisms are intended to be boosted such as the Horizon 2020, which defines the EU framework for research and innovation for 2014-2020. Establishing a bioeconomy in Europe can maintain and create economic growth and jobs in rural, coastal and industrial areas, while reducing fossil fuel dependence and improving economic and environmental sustainability. Many member States have launched bioeconomy initiatives including France, Germany, The Netherlands, Sweden and Finland. Non-European countries such as the US and China are also investing heavily into bioeconomy (McCormick and Kautto, 2013). The bioeconomy concept and the biotechnology approach taken are rather weak sustainability stances since they are

\footnotetext{
${ }^{4}$ Bioeconomy data and information website, managed by the European Commission's Joint Research Centre (JRC); Available at: https://biobs.jrc.ec.europa.eu/
} 
focused on using natural resource inputs to production processes. Weak sustainability, in environmental economics, states that 'human capital' and 'natural capital' are substitutable and that a complete change of our economic system is not required (see more in section 5.1), but rather a shifting from fossil to renewable inputs. However, (critical) limits in the supply of these inputs are not at the center of the approach. Furthermore, it is mainly a firm based micro approach since it aims at changing firm's behavior.

\subsubsection{Product-service system}

A third, relatively new, concept is the product-service system (PSS), defined in Europe in the 1990s as "a mix of tangible products and intangible services designed and combined so that they jointly are capable of fulfilling final customer needs" (Tukker and Tischner, 2006, p. 1552). Products are owned by companies along their entire lifecycles, and the use of service of the product is what the consumer pays for (Hinton, 2008). Therefore, companies have a strong economic interest to extend the lifespan of their products, to ensure that they are intensively used, to make them as cost and material efficient as possible and to re-use parts as much as possible. However, implementing a product-service system does not mean that it will by definition be more resource-efficient or circular than classical product systems. Tukker (2013) identified different categories of Product-Service System (PSS), including use-oriented PSS in which the product continues to play a central role (e.g., product renting, sharing or polling) and result-oriented PSS in which there is no predetermined product (e.g., pay per service unit). Use-oriented PSS potentially increases the use-stage of products, reducing the need for materials; however, as a possible disadvantage, it can lead to less careful behavior by the user, likely reducing the lifespan of products. The result-oriented PSS have the greatest potential to increase eco-design and resource efficiency. However, many radical changes must be made to develop this approach because firms need to change their business model and their infrastructure and to develop new skills (e.g., relation management skills) (Tukker, 2013). The concept of PSS is closely related to servicizing, or functional economy. Functional economy was proposed by Stahel in 1989 as a means to achieve sustainability (Stahel, 1989). The economic objective of functional economy is "to create the highest possible use of value for the longest time while consuming a few material resources and energy as possible" (Stahel, 1997). All these concepts can be perceived as a possible answer to dematerialize the economy (Mont, 2002) and to contribute to a resource-efficient and circular economy (Tukker, 2013).

The concept of PSS is close to dematerializing since its central idea is no longer productbased but focused on product life and functionality from which services arise: by sharing and renting the per capita resource consumption is likely to be reduced. However, even though more sustainable business models such as PSS bring green economy benefits, they remain mainly on incremental and micro level and do not aim at systematic changes in overall resource consumption patterns. We therefore locate the concept at an intermediate position between weak and strong sustainability.

\section{Mapping theories, concepts, approaches and tools: a green economy heuristic framework}

The concept of a green economy is related to several different economic theories, concepts, practical approaches and assessment tools. To clarify these links, all the most evident respective elements were integrated in a multi-layered framework (Figure 3). The purpose is to make explicit these concepts and their relationships, so that the framework can serve as a "green economy heuristic". 
First, a green economy can be linked to both theories of environmental economics and ecological economics. The implementation of these two theories in practice results in different concepts and approaches. Environmental economics is closely related to cleaner production and resource efficiency, whereas ecological economics relies on advanced concepts such as industrial ecology or circular economy. Waste hierarchy can be both related to environmental economics and ecological economics, depending on the extent to which its different approaches are implemented (down-cycling versus up-cycling). All these concepts are based on practical approaches or solutions to achieve the green economy objectives that are listed on the bottom of Figure 3, i.e., environmental, economic and social benefits.

Practical solutions for a green economy encompass a broad range of approaches that can be implemented such as reuse, repair, recover or recycling, applying eco-design rules or developing industrial symbiosis. In order to measure the effects of these solutions on green economy goals, different assessment tools can be used such as LCA, LCC, S-LCA, MFA, EEIO and CBA.

In addition, several potential emerging concepts and their related approaches have been identified as promising instruments to implement green economy strategies. These approaches include bioeconomy, which can be related to environmental economics, and nature-based solutions and PSS, which can be linked to ecological economics.

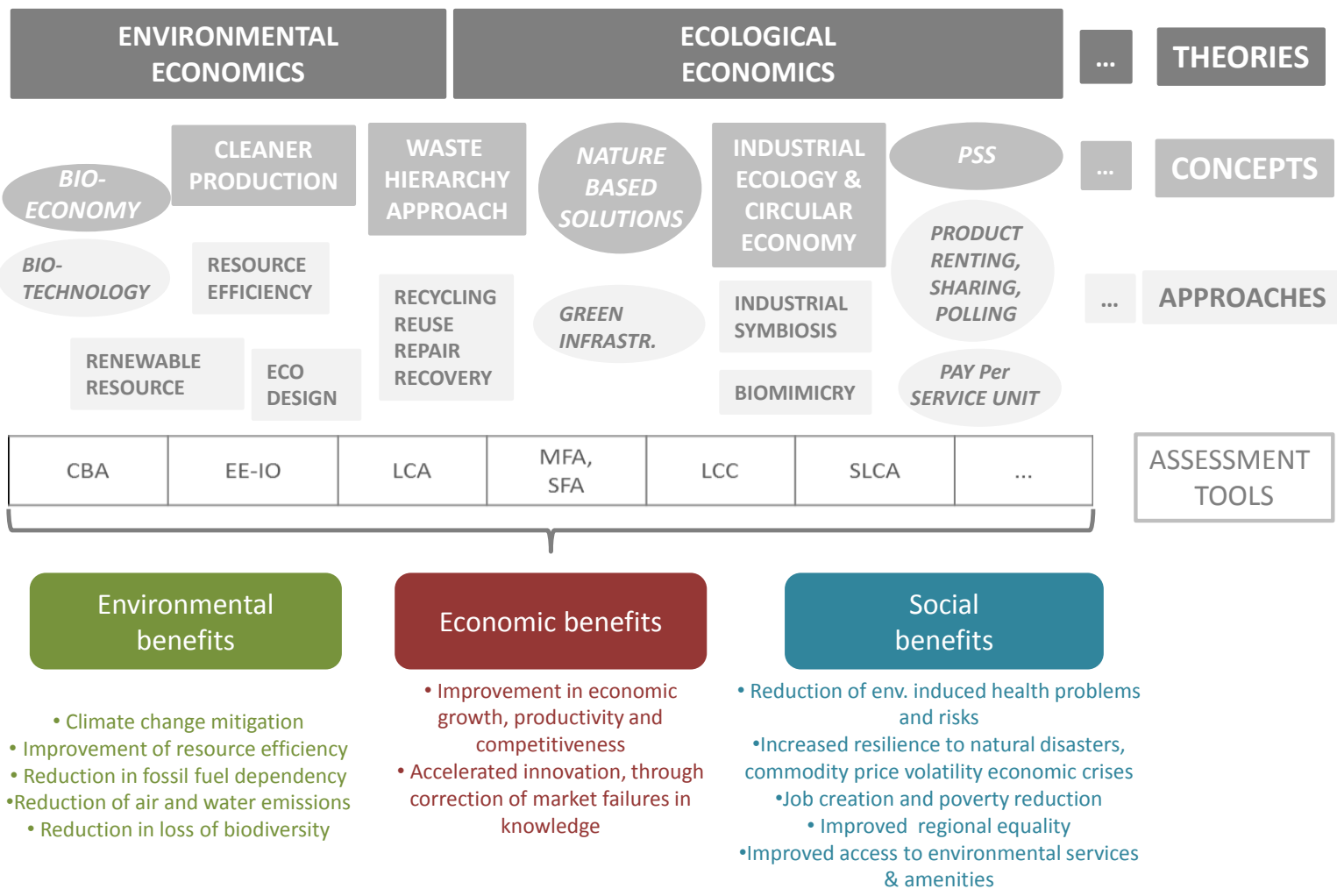

Figure 3 Generic framework showing the different layers of the green economy concept (for the concepts, current concepts are marked with boxes, emerging concepts are in circles and in italics).

\section{Discussion: Sustainability issues and policy implications}

There are several implications of our generic framework from which we choose two focal perspectives. Firstly, we consider the relationships of the theories presented, concepts, approaches and tools discussed to either weak or strong sustainability (section 5.1). Secondly, we discuss what this implies for the implementation of a green economy in the political and 
economic realm (section 5.2). When implementing the green economy in practice, there are several critical factors related to economic viability, public funding, technological development, impact assessments, public policies and regulation, social capital, leadership and coordination as well as public acceptability and image, and transition to green economies requires negotiation between potential trade-offs among multiple goals, and interests of various stakeholders (Pitkänen et al. 2016). Furthermore, limiting the action space of the "brown" economy at the least socially and environmentally friendly end is required as well and government interventions, such as regulation, public procurement; and investment, setting incentive and raising revenues, network and capacity building, and monitoring processes can help in this (Droste et al. 2016).

\subsection{Links with weak and strong sustainability}

The generic framework of a green economy shows that different concepts and approaches are available and can be used to support the transition towards sustainability. However, doubts have been expressed regarding the ability of a green economy to support the transition towards sustainability (Bina and La Camera, 2011; Lorek and Spangenberg, 2014). This doubt can be partly explained by the two different visions of sustainability that can be found in the two economics theories related to green economy, i.e., weak sustainability and strong sustainability (Dietz and Neumayer, 2007; Neumayer, 2003; Pearce and Atkinson, 1993).

Weak sustainability, in environmental economics, states that 'human capital' and 'natural capital' are substitutable and that no complete change of our economic system is required. Therefore, certain elements of concepts and approaches related to environmental economics, i.e., cleaner production, bioeconomy or waste hierarchy assume that natural capital can be substituted by human-made capital. For instance, the use of biotechnology or the quest for efficiency rely on the hypothesis that new technologies will always be developed to meet increasing human needs in a world where natural resources are limited. Similarly, the assessment tools developed in environmental economics such as CBA assume a complete substitutability between natural and human-made capital. For weak sustainability approaches, this assumption could be operationalized by an elasticity of substitution greater than one, meaning that a loss in one dimension can be offset by gains in the other (Neumayer, 2003). Nonetheless, recent developments such as the fostering of upcycling in waste hierarchy tend to consider the vulnerability of the environment and the need to preserve it.

Strong sustainability, often found in ecological economics, assumes that human-made capital and natural capital are complementary, but not limitlessly interchangeable. According to this view, concepts and approaches attempt to find solutions to maintain humanity within a safe operating space by closing the loop of material throughput (circular economy and industrial ecology) and respecting critical thresholds of natural capital stocks, and even by facilitating investments into the natural capital stock (nature-based solutions). In economic terms, elasticity of substitution between human-made capital and natural capital would be less than unity, meaning the loss natural capital cannot be offset by gains in the human made capital and their inputs are complements (Neumayer, 2003). As such these more ecological perspectives reveal primarily a macro perspective entailing the utmost system boundaries of our productive systems. These respective solutions require more structural changes in human society because they involve long-term and substantial modifications in our mode of living.

Figure 4 classifies the different concepts related to green economy according to these two features of sustainability, i.e., the level of substitution between environmental and economic benefits, and the required level of change. This figure shows that depending on which of the 
particular concepts green economy relies on, its link to sustainability will differ. The use of concepts such as cleaner production or bioeconomy requires less adaptations of human's mode of living and it assumes substitution between environmental and economic capitals. On the contrary, concepts such as PSS, industrial ecology, or nature-based solutions assume that structural changes are required in our societies to meet the challenges of sustainability. As the bibliographic analysis revealed, green economy is currently more related to concepts linked to weak sustainability (i.e., energy efficiency or pollution control) than concepts that require deep societal transformations (i.e., circular economy). This observation is supported by the fact that in the scientific literature "green economy" is more often associated to "environmental economics".

Regarding the issue of substitutability, recent works have attempted to determine biophysical limits or planetary boundaries that define the boundaries within which humanity is expected to operate safely (Rockström et al., 2009; Steffen et al., 2015). Crossing certain biophysical thresholds could have disastrous and irreversible consequences for humanity. In addition, no trade-offs between environmental dimensions are allowed because risks cannot be overcome by substituting deterioration in one biophysical boundary by improvements in others. System and product level tools such as LCA are designed to measure impacts and identify potential burden shifting (Ayres \& Ayres 2002).

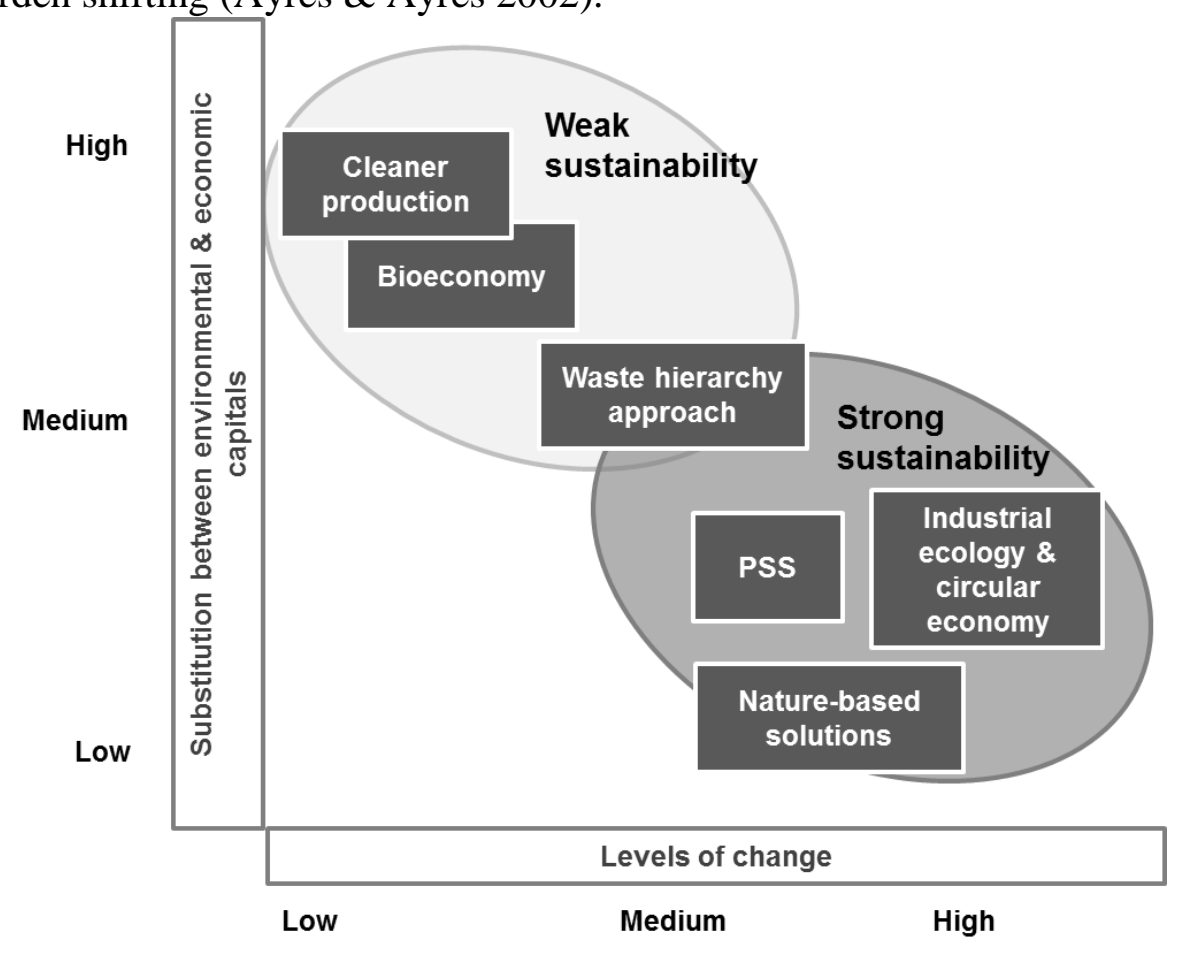

Figure 4 Classification of the different concepts related to green economy according to two sustainability visions

\subsection{Green economy as a concept for policy-making}

The concept of a green economy is very attractive to governments and businesses as it aims to provide a simultaneous solution to both unemployment and environmental issues with new green industries and tools for mitigating environmental damage (Borel-Saladin and Turok, 2013).

The UNEP Green Economy synthesis for policy makers claims that - in the long run - "the so-called 'trade-off' between economic progress and environmental sustainability is a myth" (UNEP, 2011a). This point deserves special attention because it assumes that there can be win-win solutions for both the economy and the environment (Porter and Van der Linde, 
1995). This so called "Porter hypothesis" has been widely debated and is at the core of our conceptualization of the relation of different theoretical assumptions about a feasible degree of substitutability. Considering these elements, most of the green economy debate regards the extent of changes and how to achieve these modifications (Pearce, 1992).

However, an empirical question remains about regarding how far economic activity can be decoupled from the consumption and depletion of natural resources remains unanswered. Decoupling environmental harm from economic production has two important dimensions, namely firs, the relative decoupling, where both indicators continue growing, the nominator at a slower rate, and second, the absolute decoupling, which means that the nominator is reduced over time in absolute terms (Wernick et al., 1996). For example, UNEP (2011b) has shown how relative resource decoupling is taking place, but on absolute terms, no actual reductions occur, while substantial reductions in the resource requirements of economic activities will be necessary. As fast as the coefficient between growth and environment is lowered, the problem of scale may dominate. This effect is induced by globalization and expanding market access increasing economic activity and hence, the total quantity of pollution produced. This is crucial for practical implications of a green economy, since the contradiction between the feasible degree of substitutability and the ultimate feasibility of absolute decoupling stems from mere theoretical concerns.

To clarify the different notions of a green economy we produced a heuristic framework of different theories, concepts and approaches and we discussed their relation to weak and strong sustainability visions. The framework produced in our study provides a support tool for policy makers to identify the levels of change in transition to the green economy, and thus it can be used to assess potential effectiveness of both practical cases and policy instruments.

The approaches that can be classified as weak sustainability concepts aim at cleaner production patterns and at reducing pollution and waste, which evidently is positive in terms of sustainability and green economy. Through well-designed and coherent legal frameworks, environmentally friendly and equitable behavior, private sector actors can be encouraged and incentivized to implement green economy concepts and approaches (Lee et al., 2014a, 2014b, 2014c). Regulation, charges, levies, taxes, and other market-based instruments such as tradable permit schemes can help to scale-up such investments and internalize the costs of environmental externalities (Pizzol et al., 2014) and implement the weak sustainability portion of the green economy.

The green economy concepts targeting at strong sustainability apply dematerialization, servicing, and investments into natural capital. These approaches have not yet gained a foothold in broad-scale applications, especially since they require more systemic and substantial changes in the way the economies and societies works. Although the main investment for such a shift will need to originate from the private sector (i.e., from finance, banks and insurance companies), governments will have to play a vital role in steering those investments towards greening the economy (UNEP 2011). Furthermore, governments as such will need to incorporate environmental values into their own decision making, expenditure planning, and accounting in a manner that does not deplete environmental assets (Barbier, 2011; ten Brink et al., 2012). Ultimately, any reduction of environmental impact per unit of production moves the economic system towards a more sustainable development. How strong a movement is required to safe-guard planetary boundaries is a question of socio-ecological knowledge and the potential for innovation. It may, however, require the political imposition of some boundaries for resource consumption in order to unlock the full innovative potential of a green economy. When aiming at making the win-win economy-environment developments a reality, the green economy decision makers should thus focus on the implementation of 
ecological economics approaches such as industrial ecology, circular economy and naturebased solutions of green infrastructure.

\section{Final remarks}

The concept of a "green economy" is well established in the political sphere, and it appears in many policy agendas of international institutions. However, the possible misinterpretations of the concept and the lack of proper science-based decision-support tools can hamper its use in politics. The current policies often support vested interests producing vague documents and theoretical projects delaying effective change in the distant future.

To clarify the different notions of a green economy we provided a generic framework of different theories, concepts and approaches and discussed their relation to weak and strong sustainability. Depending on the solution chosen, required changes to implement green economy strategies can be more or less incremental. Certain solutions are more compliant with mainstream economy and require few changes, e.g., cleaner production defined as adapted for efficiently green production, whereas other solutions are based on deep transformations of our patterns of production and consumption like industrial ecology or nature-based solutions that require large-scale investments into green infrastructure. Regarding the feasibility of an actual implementation of the Porter hypothesis, we conclude that the green economy decision makers might want to consider a more ecological economics or strong sustainability stance if the win-win, green economy ideas of a thriving human wellbeing within planetary boundaries are to come true. At this point major knowledge gaps exist on how this shift will be implemented in practice. Different economic sectors also may require different measures. This can be documented and guidance provided if specifically addressed in future studies on greening economy.

\section{Acknowledgements}

The authors appreciate the funding of the "Green Economy Initiative" by the PEER institutes "Partnership for European Environmental Research".

\section{References}

Ambec, S., Cohen, M. A., Elgie, S., Lanoie, P. (2013). The Porter hypothesis at 20: can environmental regulation enhance innovation and competitiveness? Review of Environmental Economics and Policy, 0(0), 1-22. doi:10.1093/reep/res016

Allenby, B. 2006. The ontologies of industrial ecology? Progress in Industrial Ecology, An International Journal (PIE) 3 (1/2): 28-40.

Ayres, R. \& Ayres, L. (Eds.) 2002. A handbook of industrial ecology. Edward Elgar, Cheltenham, UK.

Barbier, E., 2012. The Green Economy Post Rio+20. Science (80-. ). 338, 887-888.

Barbier, E., 2011. The policy challenges for green economy and sustainable economic development. Nat. Resour. Forum 35, 233-245. doi:10.1111/j.1477-8947.2011.01397.x

Bartl, A., 2014. Moving from recycling to waste prevention: A review of barriers and enables. Waste Manag. Res. 32, 3-18.

Benoit Norris, C., 2012. Social Life Cycle Assessment: A Technique Providing a New Wealth 
Author-produced version of the article published in Journal of Cleaner Production, 2016, N¹39, p.361-371

The original publication is available at http://www.sciencedirect.com

Doi: 10.1016/j.jclepro.2016.08.024

of Information to Inform Sustainability-Related Decision Making, in: Curran, M.A. (Ed.), Life Cycle Assessment Handbook. Wiley Online Library, pp. 433-450.

Bina, O., La Camera, F., 2011. Promise and shortcomings of a green turn in recent policy responses to the "double crisis." Ecol. Econ. 70, 2308-2316. doi:10.1016/j.ecolecon.2011.06.021

Bonaiuti, M. 2011. From Bioeconomics to Degrowth. Nicholas Georgescu-Roegen "New Economics" in Eight essays"', Routledge.

Borel-Saladin, J.M., Turok, I.N., 2013. The green economy: Incremental change or transformation? Environ. Policy Gov. 23, 209-220. doi:10.1002/eet.1614

Bringezu, S., Moriguchi, Y., 2002. Material Flow Analysis, in: Ayres, R.U., Ayres, L.W. (Eds.), A Handbook of Industrial Ecology. Edward Edgar, Cheltenham, UK, pp. 288300.

Chertow, M.R., 2000. Industrial symbiosis. Literature and taxonomy. Annu. Rev. Energy Environ. 25, 313-337.

de Bruyn, S., 2002. Dematerialization and rematerialization as two recurring phenomena of industrial ecology, in: Ayres, R.U., Ayres, L.W. (Eds.), A Handbook for Industrial Ecology. Cheltenham, UK, pp. 209-222.

Dietz, S., Neumayer, E., 2007. Weak and strong sustainability in the SEEA: Concepts and measurement. Ecol. Econ. 61, 617-626. doi:10.1016/j.ecolecon.2006.09.007

Droste, N., Hansjürgens, B., Kuikman, P., Antikainen, R., Leskinen, P., Pitkänen, K., Saikku, L., Loiseau, E., Thomsen, M., 2015. Supporting innovations towards Green Economy transition - analysing governance factors and government intervention in five European cases. J. Clean. Prod. 135: 426-434. doi:10.1016/j.jclepro.2016.06.123

EC, 2008. Directive 2008/98/EC of the European Parliament and of the Council of 19 November 2008 on waste and repealing certain Directives.

EEA, 2014. Resource-efficient green economy and EU policies. European Environment Agency. doi:10.2800/18514

Ehrenfeld, J., Gertler, N., 1997. Industrial Ecology in Practice: The Evolution of Interdependence at Kalundborg. J. Ind. Ecol. 1, 67-79. doi:10.1162/jiec.1997.1.1.67

Ekins, P., Simon, S., Deutsch, L., Folke, C., De Groot, R., 2003. A framework for the practical application of the concepts of critical natural capital and strong sustainability. Ecol. Econ. 44, 165-185. doi:10.1016/S0921-8009(02)00272-0

El Kholy, O.A., 2002. Cleaner Production, in: Encyclopedia of Global Environmental Change. John Wiley \& Sons.

European Commission, 2013a. Building a Green Infrastructure for Europe. European Union, Brussels. doi:10.2779/54125

European Commission, 2013b. Green Infrastructure (GI) — Enhancing Europe's Natural Capital.

European Commission, 2012. Communication from the Commission of the European Parliament, the Council, the European economic and social Committee and the Committee of the Regions: "Innovating for Sustainable Growth: A Bioeconomy for 
Author-produced version of the article published in Journal of Cleaner Production, 2016, N¹39, p.361-371

The original publication is available at http://www.sciencedirect.com

Doi: 10.1016/j.jclepro.2016.08.024

Europe.” Brussels.

Falagas, M.E., Pitsouni, E.I., Malietzis, G. a, Pappas, G., 2008. Comparison of PubMed, Scopus, Web of Science, and Google Scholar: strengths and weaknesses. FASEB J. 22, 338-342. doi:10.1096/fj.07-9492LSF

Farley, J., 2008. The role of prices in conserving critical natural capital. Conserv. Biol. 22, 1399-408. doi:10.1111/j.1523-1739.2008.01090.x

Finnveden, G., Hauschild, M.Z., Ekvall, T., Guinée, J., Heijungs, R., Hellweg, S., Koehler, A., Pennington, D., Suh, S., 2009. Recent developments in Life Cycle Assessment. J. Environ. Manage. 91, 1-21. doi:10.1016/j.jenvman.2009.06.018

Georgescu-Roegen, N. 1975. Energy and economic myths. Southern Economic Journal 41 (3): 347-381.

Guinée, J.B., Heijungs, R., Huppes, G., Zamagni, A., Masoni, P., Buonamici, R., Ekvall, T., Rydberg, T., 2011. Life cycle assessment: past, present, and future. Environ. Sci. Technol. 45, 90-96. doi:10.1021/es101316v

Hanley, N., Barbier, E.B., 2009. Pricing Nature: Cost-benefit Analysis and Environmental Policy. Edward Elgar, Cheltenham.

Hanley, N., Spash, C., 1993. Cost-benefit analysis and the environment. Edward Elgar, Cheltenham.

Hansjürgens, B., 2004. Economic valuation through cost-benefit analysis - possibilities and limitations. Toxicology 205, 241-252. doi:10.1016/j.tox.2004.06.054

Heijungs, R., 2010. Ecodesign —Carbon Footprint—Life Cycle Assessment—Life Cycle Sustainability Analysis. A Flexible Framework for a Continuum of Tools. Sci. J. Riga Tech. Univ. Environ. Clim. Technol. 4, 42-46.

Herring, H. 2006. Energy efficiency - a critical view. Energy 31(1), 10-20.

Hill, J., 2015. Circular Economy and the Policy Landscape in the UK, in: Clift, R., Druckman, A. (Eds.), Taking Stock of Industrial Ecology. Springer.

Hinton, J., 2008. Is the circular economy ambitious enough? A look at incorporating PSS (product-service systems) into China's leapfrog development strategy. Lund University, Sweden.

Hoogmartens, R., Van Passel, S., Van Acker, K., Dubois, M., 2014. Bridging the gap between LCA, LCC and CBA as sustainability assessment tools. Environ. Impact Assess. Rev. $48,27-33$.

Jänicke, M., 2012. "Green growth": From a growing eco-industry to economic sustainability. Energy Policy 48, 13-21. doi:10.1016/j.enpol.2012.04.045

Kennet, M., Heinemann, V., 2006. Green Economics: setting the scene. Aims, context, and philosophical underpinning of the distinctive new solutions offered by Green $\mathrm{E}$ conomics. Int. J. Green Econ. 1, 68-102.

Kitzes, J., 2013. An introduction to environmentally-extended input-output analysis. Resources 2, 489-503.

Koskela, S., Maenpaa, I., Seppäläa, J., Mattila, T.J., Korhonen, M.-R., 2011. EE-IO modeling of the environmental impacts of Finnish imports using different data sources. Ecol. Econ. 70, 2341-2349. 
Author-produced version of the article published in Journal of Cleaner Production, 2016, N¹39, p.361-371

The original publication is available at http://www.sciencedirect.com

Le Blanc, D., 2011. Special issue on green economy and sustainable development. Nat. Resour. Forum 35, 151-154. doi:10.1111/j.1477-8947.2011.01398.x

Lee, J., Lee, J.H., Kim, C.K., Thomsen, M., 2014a. Childhood exposure to DEHP, DBP and BBP under existing chemical management systems: A comparative study of sources of childhood exposure in Korea and in Denmark. Environ. Int. 63, 77-91.

Lee, J., Pedersen, A.B., Thomsen, M., 2014b. Are the resource strategies for sustainable development sustainable?: Downside of a zero waste society with circular resource flows. Environ. Technol. Innov. 1-2, 46-54.

Lee, J., Pedersen, A.B., Thomsen, M., 2014c. The influence of resource strategies on childhood phthalate exposure-The role of REACH in a zero waste society. Environ. Int. 73, 312-322.

Leontief, W., 1936. Quantitative input and output relations in the economic system of the United States. Rev. Econ. Stat. 18.

Lifset, R.J., Graedel, T., 2002. Industrial ecology: goals and definitions, in: Ayres, R.U., Ayres, L.W. (Eds.), A Handbook of Industrial Ecology. Edward Edgar, Cheltenham, UK, pp. 3-15.

Lombardi, D.R., Laybourn, P., 2012. Redifining industrial symbiosis. Crossing academicpractioner boundaries. J. Ind. Ecol. 16, 28-37.

Lorek, S., Spangenberg, J.H., 2014. Sustainable consumption within a sustainable economy Beyond green growth and green economies. J. Clean. Prod. 63, 33-44. doi:10.1016/j.jclepro.2013.08.045

Macombe, C., Lagarde, V., Falque, A., Feschet, P., Garrabé, M., Gillet, C., Loeillet, D., 2013. Social LCAs. Socio-economic effects in value chains, 1 srt Editi. ed. FruiTrop, CIRAD.

Mathews, J.A., 2012. Green growth strategies-Korean initiatives. Futures 44, 761-769. doi:10.1016/j.futures.2012.06.002

Mathews, J.A., Tan, H., 2011. Progress toward a circular economy in China: The drivers (and inhibitors) of eco-industrial initiative. J. Ind. Ecol. 15, 435-457. doi:10.1111/j.15309290.2011.00332.x

Mazza, L., Bennett, G., De Nocker, L., Gantioler, S., Losarcos, L., Margerison, C., Kaphengst, T., McConville, A., Rayment, M., ten Brink, P., Tucker, G., van Diggelen, R., 2011. Green infrastructure implementation and efficiency. Institute for European Environmental Policy, Brussels.

Mazza, L., ten Brink, P., 2012. Green Economy in the European Union. Supporting briefing, with support from Fedrigio-Fazio, D. UNEP, IIEP \& Globe European Union - EU. Available at: http://www.unep.org/pdf/Supporting_Brief_2012.pdf

McCormick, K., Kautto, N., 2013. The Bioeconomy in Europe: An Overview. Sustainability 5, 2589-2608. doi:10.3390/su5062589

Mont, O.K., 2002. Clarifying the concept of product-service system. J. Clean. Prod. 10, 237245. doi:10.1016/S0959-6526(01)00039-7

Navarro, L. M., \& Pereira, H. M. (2012). Rewilding abandoned landscapes in Europe. Ecosystems, 15(6), 900-912. doi:10.1007/s10021-012-9558-7

Nellemann, C., Corcoran, E., (eds), 2010. Dead Planet, Living Planet - Biodiversity and 
Author-produced version of the article published in Journal of Cleaner Production, 2016, N¹39, p.361-371

The original publication is available at http://www.sciencedirect.com

Doi: 10.1016/j.jclepro.2016.08.024

Ecosystem Restoration for Sustainable Development. A Rapid Response Assessment., Challenges. United Nations Environment Programme, GRID-Arendal.

Neumayer, E., 2003. Weak versus strong sustainability: exploring the limits of two opposing paradigms.

OECD, 2011. Towards Green Growth: Monitoring Progress. doi:10.1787/9789264111318-en

OECD, 2009. The Bioeconomy to 2030: desingning a policy agenda.

Pearce, D., 1992. Green Economics. Environ. Values 1, 3-13.

Pearce, D., Atkinson, G., 1993. Capital theory and the measurement of sustainable development: an indicator of "weak" sustainability 8, 103-108. doi:10.1016/09218009(93)90039-9

Pearce, D., Markandya, A., Barbier, E., 1989. Blueprint for a green economy. Earthscan, London, Great Britain.

Pearce, D., Moran, D., 1994. The Economic Value of Biodiversity. Earthscan, London.

Pelenc, J., Ballet, J., 2015. Strong sustainability, critical natural capital and the capability approach. Ecol. Econ. 112, 36-44. doi:10.1016/j.ecolecon.2015.02.006

Pfeiffer, F., Rennings, K., 2001. Employment impacts of cleaner production - Evidence from a German study using case studies and surveys. Bus. Strateg. Environ. 10, 161-175.

Pigou, A.C., 1920. The Economics of Welfare, 4th ed. Macmillan and Co, London, Great Britain.

Pitkänen, K., Antikainen, R., Droste, N., Loiseau, E., Saikku, L., Aissani, L., Hansjürgens, B., Kuikman, P., Leskinen, P., Thomsen, M., 2015. Implementing green economy in practice: Learnings from European case studies. Submitt. to J. Clean. Prod.

Pizzol, M., Smart, J.C.R., Thomsen, M., 2014. External costs of cadmium emissions to soil: a drawback of phosphorus fertilizers. J. Clean. Prod. 84, 475-483.

Porter, M.E., Van der Linde, C., 1995. Green and Competitive: Ending the Stalemate. Harv. Bus. Rev. 73, 120-134.

Rennings, K., Wiggering, H., 1997. Steps towards indicators of sustainable development: Linking economic and ecological concepts. Ecol. Econ. 20, 25-36. doi:10.1016/S09218009(96)00108-5

Rockström, J., Steffen, W., Noone, K., Persson, Å., Chapin, F.S., Lambin, E.F., Lenton, T.M., Scheffer, M., Folke, C., Schellnhuber, H.J., Nykvist, B., de Wit, C.A., Hughes, T., van der Leeuw, S., Rodhe, H., Sörlin, S., Snyder, P.K., Costanza, R., Svedin, U., Falkenmark, M., Karlberg, L., Corell, R.W., Fabry, V.J., Hansen, J., Walker, B., Liverman, D., Richardson, K., Crutzen, P., Foley, J.A., 2009. A safe operating space for humanity. Nature 461, 472-475.

Roy, R., 2000. Sustainable product-service systems. Futures 32, 289-299. doi:10.1016/S0016-3287(99)00098-1

Schmid, O., Padel, S., Levidow, L., 2012. The Bio-Economy Concept and Knowledge Base in a Public Goods and Farmer Perspective. Bio-based Appl. Econ. 1, 47-63.

Sen, A., 2000. The Discipline of Cost-Benefit Analysis. J. Legal Stud. 29, 931-952. doi:10.1086/468100 
Author-produced version of the article published in Journal of Cleaner Production, 2016, N¹39, p.361-371

The original publication is available at http://www.sciencedirect.com

Sesana, M.M., Salvalai, G., 2013. Overview on life cycle methodologies and economic feasibility for nZEBs. Build. Environ. 67, 211-216.

Stahel, W. R. 1997. The functional economy: cultural and organizational change; in: Richards, Deanna J., The industrial green game, 1997, National Academy Press, Washington DC. p. 91-100.

Stahel, W.R., 1989. The limits to certainty: facing risks in the new servuce economy. Kluwer Academic Publishers, Dordrecht.

Steffen, W., Richardson, K., Rockström, J., Cornell, S., Fetzer, I., Bennett, E., Biggs, R., Carpenter, S.R., de Wit, C. a., Folke, C., Mace, G., Persson, L.M., Veerabhadran, R., Reyers, B., Sörlin, S., 2015. Planetary Boundaries: Guiding human development on a changing planet. Science (80-. ). 347. doi:10.1126/science.1259855

Sterr, T., Ott, T., 2004. The industrial region as a promising unit for eco-industrial development - reflections, practical experience and establishment of innovative instruments to support industrial ecology. J. Clean. Prod. 12, 947-965. doi:10.1016/j.jclepro.2004.02.029

TEEB, 2010. The Economics of Ecosystems and Biodiversity: The Ecological and Economic Foundations. Earthscan, London and Washington.

ten Brink, P., Mazza, L., Badura, T., Kettunen, M., Withana, S., 2012. Nature and its Role in the Transition to a Green Economy. Brussels.

The Ellen MacArthur Foundation, 2012. Towards circular economy: Economic and business rationale for an accelerated transition.

The World Bank, 2012. Inclusive Green Growth: The Pathway to Sustainable Development. Washington D.C. doi:10.1596/978-0-8213-9551-6

Tukker, A., 2013. Product services for a resource-efficient and circular economy - a review. J. Clean. Prod. 97, 76-91. doi:10.1016/j.jclepro.2013.11.049

Tukker, A., Tischner, U., 2006. Product-services as a research field: past, present and future. Reflections from a decade of research. J. Clean. Prod. 14, 1552-1556. doi:10.1016/j.jclepro.2006.01.022

Tzoulas, K., Korpela, K., Venn, S., Yli-Pelkonen, V., Kaźmierczak, A., Niemela, J., James, P., 2007. Promoting ecosystem and human health in urban areas using Green Infrastructure: A literature review. Landsc. Urban Plan. 81, 167-178. doi:10.1016/j.landurbplan.2007.02.001

UNEP, 2016. Sustainable Consumption \& Production Branch: Resource Efficient and Cleaner Production [WWW Document]. URL http://www.unep.fr/scp/cp/

UNEP, 2015. Using product-service systems to enhance sustainable public procurement.

UNEP, 2011a. Towards a Green Economy: Pathways to Sustainable Development and Poverty Eradication. doi:10.1063/1.3159605

UNEP, 2011b. UNEP (2011) Decoupling natural resource use and environmental impacts from economic growth, A Report of the Working Group on Decoupling to the International Resource Panel. Fischer-Kowalski, M., Swilling, M., von Weizsäcker, E.U., Ren, Y., Moriguchi, Y., Crane, W., Krausmann, F., Eisenmenger, N., Giljum, S., Hennicke, P., Romero Lankao, P., Siriban Manalang, A. 
van den Bergh, J.C.J.M., 2001. Ecological economics: themes, approaches, and differences with environmental economics. Reg. Environ. Chang. 2, 13-23. doi: $10.1007 / \mathrm{s} 101130000020$

Vatn, A., 2007. Institutions and the Environment. Edward Elgar, Cheltenham.

Wernick, I.K., Herman, R., Govind, S., Ausubel, J., 1996. Materialization and dematerialization: Measures and trends. Daedalus 125, 171-198.

Williams, C.C., Millington, A.C., 2004. The diverse and contested meaning of sustainable development. Geogr. J. Vol. 170, pp. 99-104.

Williamson, O.E., 1994. The Institutions and Govemance of Economic Development and Reform. Proceeings of the World Bank Annual Conference on Development Economics, 171-196.

World Commission on Environment and Development, 1987. Our common future. Oxford. 